\title{
SYNCHRONOUS AND ASYNCHRONOUS WITH FLIPPED LEARNING ENVIRONMENT IN PRIMARY SCHOOL
}

\author{
Ida Rindaningsih"1, Yulian Findawati², Wiwik Dwi Hastuti ${ }^{3}$, Eni Fariyatul Fahyuni4 \\ ${ }^{1}$ Muhammadiyah University Of Sidoarjo \\ ${ }^{2}$ Muhammadiyah University Of Sidoarjo \\ ${ }^{3}$ State University Of Malang \\ ${ }^{4}$ Muhammadiyah University Of Sidoarjo \\ 1rindaningsih1@umsida.ac.id, ${ }^{2}$ yulianfindawati@umsida.ac.id, ${ }^{3}$ wiwik.dwi.fip@um.ac.id, \\ eni.fariyatul@umsida.ac.id
}

\begin{abstract}
The challenges of learning during the pandemic are currently a big task for the world of education. The unpreparedness of school institutions, students, and parents in facing changes in the distance learning system has an impact on the implementation of learning during the COVID-19 pandemic. For this reason, it is necessary to have a learning solution that can answer the challenges of learning using digital-based learning. This research aims to develop a model of the reverse learning environment. This development research examines various aspects of the needs of the student learning environment during the COVID-19 pandemic. The subjects of this study were school principals, deputy principals, and elementary school teachers who have implemented the 2013 Curriculum. The results of this study show that the synchronous and asynchronous framework with the reverse learning environment approach is proven valid and feasible applied to learning COVID-19. The findings synchronous, and asynchronous that are implemented efficiently by the teacher, and applications will continue to be developed.
\end{abstract}

Keywords: Synchronous, Asynchronous, Flipped learning

\begin{abstract}
Abstrak
Tantangan pembelajaran di masa pandemic saat ini menjadi tugas besar bagi dunia pendidikan. Ketidaksiapan Lembaga sekolah, siswa dan orangtua dalam menghadapi perubahan sistem pembelajaran jarak jauh berdampak bagi pelaksanaan pembelajaran di masa pandemic COVID-19. Untuk itu perlu adanya solusi pembelajaran yang mampu menjawab tantangan pembelajaran di masa pandemic menggunakan pembelajaran berbasis digital. Tujuan penelitan ini adalah mengembangkan model lingkungan flipped learning. Penelitian pengembangan ini mengkaji berbagai aspek kebutuhan lingkungan belajar siswa pada masa pandemi COVID-19. Subject penelitian ini adalah kepala sekolah, wakil kepala sekolah dan para guru sekolah dasar yang telah menerapkan kurikulum 2013. Hasil penelitian pengembangan ini menunjukkan kerangka sinchronous dan asinchronous dengan pendekatan lingkungan flipped learning yang diterapkan terbukti valid dan layak diterapkan pada pembelajaran di masa pandemic. Temuan dalam penelitian ini kerangka sinchronous dan asinchronous yang mudah dipahami guru dan akan terus dikembangkan aplikasi pembelajaraannya.
\end{abstract}

Kata Kunci: Sinchronous, Asinchronous, Flipped learning

\section{INTRODUCTION}

Changes in learning during the COVID-19 pandemic. becomes a challenge as well as an opportunity for teachers to continue to upgrade and innovate in learning.(Daniel, 2020). Learning in the classroom shifts to synchronous, and learning outside the classroom shifts to asynchronous and projects by maximizing the immediate environment. The emphasis of learning always follows advances in educational technology; researchers believe that the learning environment is one of the factors to meet the diverse needs of students. (Murphy, 
Rodríguez-Manzanares, \& Barbour, 2011). Students must take advantage of a self-contained learning environment with learning awareness settings on learning speed, information flow, selection of learning activities, and time management. Personalization of the learning environment emphasizes individuals who are valid during the learning process increasingly important when distance learning is digital (Shahabadi \& Uplane, 2015). The need for a combination of synchronous and asynchronous to create an ideal learning environment (Perveen, 2016).

Distance learning becomes a problem in student learning styles. Research in India, found to prefer assimilation and divergent types, while asynchronous learners prefer conformity and convergent types (Shahabadi \& Uplane, 2015). The need for a combination of synchronous and asynchronous to create an ideal learning environment (Perveen, 2016). In the Philippines, learning model developed that focused on diverging and converging in facing the new normal (Gonzales, 2020). Educators who have studied in depth how to teach appropriate learning modeling for times of pandemic COVID-19 (Bakker \& Wagner, 2020). Few information is available for schools to develop learning policies and procedures. Additional research and guidance is needed to assess the appropriateness and effectiveness of school practices for improving learning with students while maintaining social distancing. (UscherPines et al., 2020). Use of seamless mobile media with teachers who integrate Islamic values and science is one of the supporting efforts government programs by implementing childfriendly learning aims to facilitate and assist the learning of students who are noble, productive, creative, innovative and able to contribute to society, nation, state, and world (Fahyuni \& et al., 2020).

The learning design can meet the learning needs of a pandemic COVID-19 to learn instruct outside the classroom. There is collaboration between online or synchronous arrangements with asinchronous activities, before and after a framework session that takes time for collaboration, discussion, problem management and applications. Teachers When in class to provide support to help students' difficulties in understanding the material (Chrissi, 2020). Students, when in class, are motivated to reflect on and consolidate learning. And outside the classroom, students learn about teacher-provided videos (Bergmann \& Sams, 2012). In the Philippines, based on the survey results, it was found that flipped learning and Enriched Virtual Learning were effective learning models during a pandemic COVID-19 (Gonzales, 2020). Recent research shows that learning to flip and prepare peers can be a valuable strategy to reward students who are active and deeply involved in the learning process at all levels in 
higher education (Chrissi, 2020). Therefore, it is essential to do this research to develop a synchronous and asynchronous framework with a reverse learning environment approach. This will provide a learning model solution for teachers and further develop a flipped classroom application that can be used by teachers and students both during the pandemic and during the pandemic era COVID-19.

An asynchronous environment provides material for students in the form of audio/video, leaflets, articles, and power point presentations. This material can be accessed anytim,e, anywhere, through the Learning Management System (LMS) (Perveen, 2016). Therefore, learning needs to be student-centered (Murphy et al., 2011). Virtual synchronous is a place for teachers and students to access and collaborate in real-time using the class discussion feature packaged online via the internet. Lessons can be added to the electronic library. Synchronization mode instills a sense of community through collaborative learning (Teng, Chen, Kinshuk, \& Leo, 2012) Synchronous virtual classrooms are places for instructors and students to be accessed and collaborated in real time. Using a web camera and class discussion features, traditional class, except that all participants access it remotely via the Internet. Lessons can be added and added to the electronic library (Perveen, 2016).

Models of Technology Use for Instruction

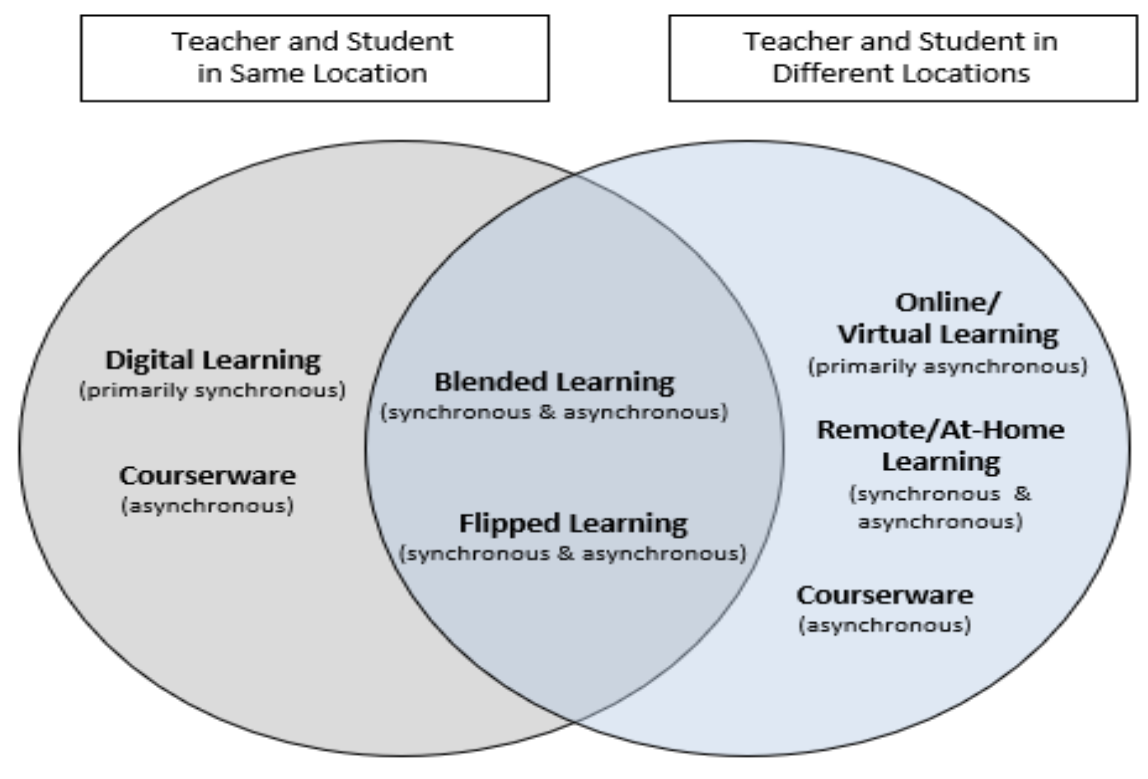

Figure 1. Models of Technology Use for Instruction (Bergland, 2020)

Based on the figure 1, it explains reverse learning, including the mixed learning section that uses the synchronous and asynchronous approaches. 
Flipped learning improves home-to-class learning. So usually in the classroom, students who listen to lectures and instructions from the teacher then go home to complete all assignments from school, but by reversing the learning, it becomes upside down between activities at home and at school. Students When at home they have studied the material for tomorrow by reading literature, assimilating the material through the next video the next day when in class, students are active in presenting and already have a provision of knowledge about the problems that are guided by the teacher through analysis and discussion (Nouri, 2016).

In Australia, it has been found that it requires criticality on the part of teachers to identify whether reverse learning would be the most suitable approach to use in certain situations. It is crucial for teachers and students to familiarize themselves with flipped learning to get maximum learning outcomes and learning independenc (Findlay-Thompson \& Mombourquette, 2014). Research on learning in the COVID 19 era shows that there is a need for pragmatic guidance to teachers, heads of institutions, and state officials who must step up education from this crisis. Guidelines include: preparations made by the system, student needs at various levels and stages, guarantees for students and teachers, straightforward approaches to distance learning, measurement, sustainability after COVID 19, and useful resources (Daniel, 2020).

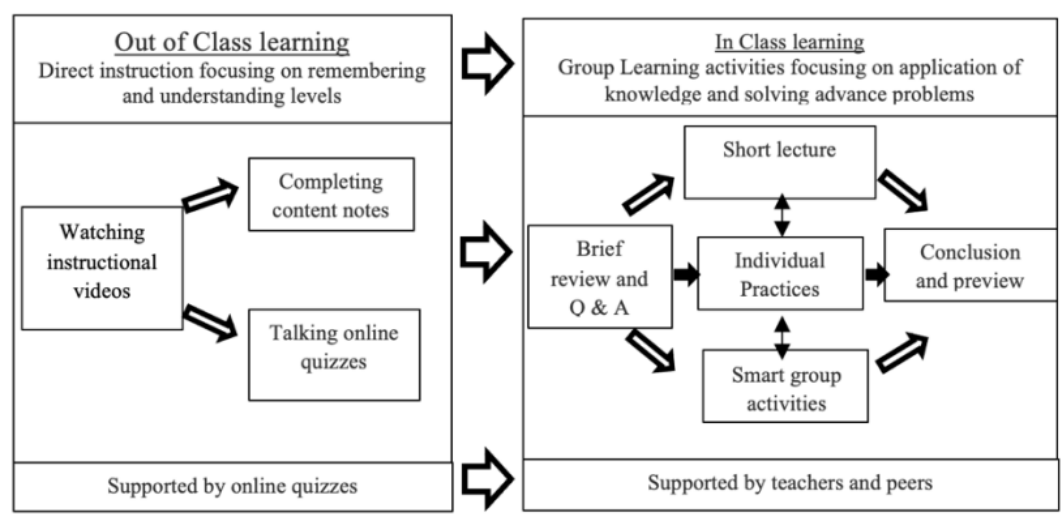

Figure 2. Flipped learning (Lo \& Hew, 2017)

In Figure 2, the strategy outside the classroom uses direct instruction (Bishop \& Verleger, 2013) focuses on the level of understanding of remembering and understanding (Lai dan Hwang 2016). The classroom learning carried out by the teacher is to explain the meaning of the assignment in the video to find out students' knowledge as well as to clarify misunderstandings (DeSantis, Curen, Putsch, \& Metzger, 2015). Students can study groups based on the material on the video with the support of teachers and peers.(Lo \& Hew, 2017). 
Cognitive achievement in the taxonomy develops a revised edition, where students build their knowledge from $\mathrm{C} 1$ and $\mathrm{C} 2$ and when students are outside the classroom or at home, build their knowledge with attainments C3 to C6.(Kvashnina \& Martynko, 2016).

The teacher's role is to help students become independent in learning and be able to foster themselves to learn. Teachers must design and implement effective strategies that facilitate learning by creating a supportive environment, one that fosters independence, not dependency (Chrissi, 2020). Today's revolutionary learning environment is one that is smart and provides new suggestions for technology solutions. Flipped learning can be an alternative in the perspective of a smart learning environment in the future (Kinshuk, Chen, Cheng, \& Chew, 2016). Flipped learning can increase learning independence for low achieving students. The results showed that students value learning using video material, learning opportunities at their own pace, more flexibility and mobility of learning that is easy and effective for students to access. (Nouri, 2016).

\section{METHOD}

This research includes developmental and quantitative research which begins in the first year of developing instructional designs using R \& D (Dick, W dan Carey, 2009). The second year the instructional design trials. For the effectiveness of the synchronous and asynchronous framework with a flipped learning environmental approach, the research team conducted 3 data methods, namely triangulation, and FGD in the first year and the second year, the researcher started with a focus on observing teacher performance in the reversing learning model so that this data would be carried out. further research related to student learning.

Based on preliminary data, the researcher used a population of 70 teachers, and it was obtained that $96 \%$ of the teachers did not understand synchronous and asynchronous. To apply the flipped learning model, researchers used respondents as many as 20 teachers from 5 schools who focused on grade 3, 4 and 5 teachers in elementary schools. Furthermore, the research team provided training related to activities in the flipped learning model for 2 weeks. The questionnaire consisted of 15 questions about the effectiveness of the learning model for teachers during the pandemic. Data analysis obtained quantitative data in the form of each item of the instrument using a Likert score of $1-5$. The researcher served a number of teachers when processing at asynchronous and synchronous indicator to see the effect of reversing learning models on teacher performance. 


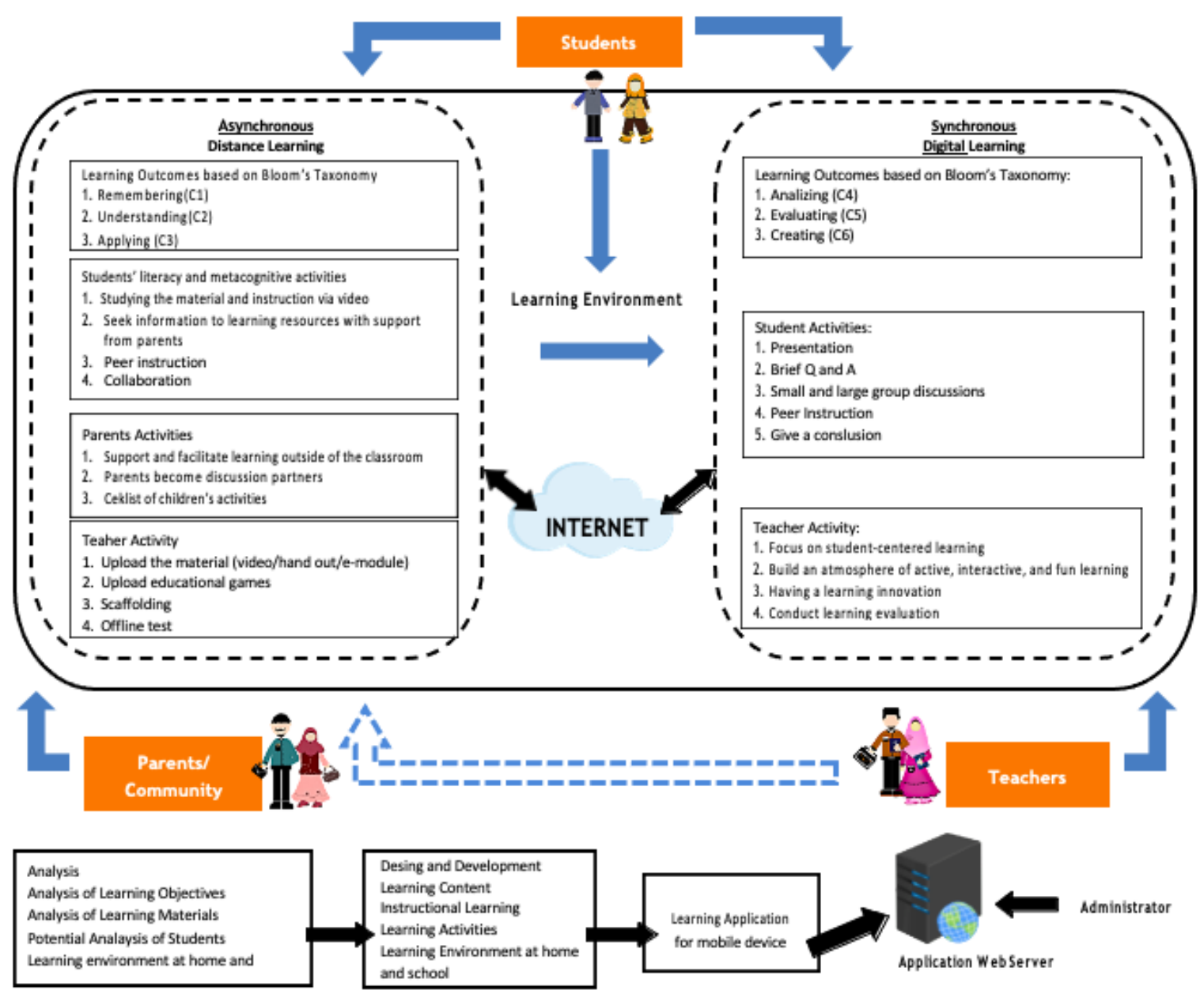

Figure 3. Flipped Learning Design with Synchronous dan Asynchronous

Based on Figure 2, there are parents or communities who take lessons outside the classroom or at home. Students are actively involved in asynchronous learning as well as synchronous learning. Meanwhile, the teacher plays an active role in classroom learning as a facilitator. Learning starts outside the classroom and at home. During the process of understanding the material to analyzing the material, a learning environment has been created that supports learning. Internet support is used wisely and supervised by parents and teachers.

Learning outcomes for students are $\mathrm{C} 1$ - C3. Therefore the teacher prepares material in the form of video learning, handouts, and educational games packaged digitally. The limitations of the teacher in understanding documentation technology in a professional manner are that the teacher provided with training in communication and professional shooting for video learning. The teacher also provides training for adequate material preparation for students. Also, the teacher is given instruction in presenting the content to make it enjoyable. Even the teacher provides training in making game education. After the teacher upgrades their competence, then the teacher uploads material in the form of videos, handouts, modules, and 
educational games. The teacher does not play an active role when it is asynchronous, but the teacher suggests providing scaffolding and giving proper instructions.

Learning is carried out in a full student center, for that teachers must be able to build an active, interactive, and fun learning atmosphere. Also, it takes teacher skills in using the right combination of strategies and learning models. Furthermore, the teacher prepares to give questions and be a listener of the presentation and material presented by the students. To be able to implement synchronous and asynchronous framework with the flipped learning approach, the researcher can arrange the instruments as follows:

Table 1. Synchronous and Asynchronous With Flipped Learning

\begin{tabular}{|c|c|}
\hline Asynchronous & Synchronous \\
\hline $\begin{array}{l}\text { 1. Tasks that support literacy, collaboration, learning } \\
\text { awareness, and learning independence. } \\
\text { 2. Video / Audio learning that is simple, interesting and } \\
\text { interactive } \\
\text { 3. Evaluation of learning both online and offline }\end{array}$ & $\begin{array}{l}\text { 1. Online learning strategies } \\
\text { 2. Presentation of online material that is } \\
\text { attractive, concise and clear } \\
\text { 3. Mastering online teaching skills to be } \\
\text { effective and efficient }\end{array}$ \\
\hline
\end{tabular}

\section{RESULTS AND DISCUSSION}

\section{Results}

The results of the study show the high category of performance in asynchronous teacher performance because the teacher is familiar with the assignment and preparation of tests when in physical classes with exam papers or student worksheets which are then converted into assignments and tests in virtual form. The existence of new experiences in presenting videos is a motivation for teachers to always improve their competence. The results of teacher performance at synchronous can be categorized as high, although not significant.

Teachers have tried to adapt to virtual learning and position themselves as facilitators. When meeting online, the teacher has been able to make students actively present their previous learning results. High student enthusiasm shows that the teacher is ready to improve higher skills. The main difficulty, both synchronous and asynchronous, is when the teacher has to face the monitor screen through the camera. Teachers are still not familiar with students through monitors and are not used to changing physical classroom learning to using video.

The focus of this research is to collect observations of teacher performance using an inverted learning model through a synchronous and asynchronous framework. The following are the responses. 


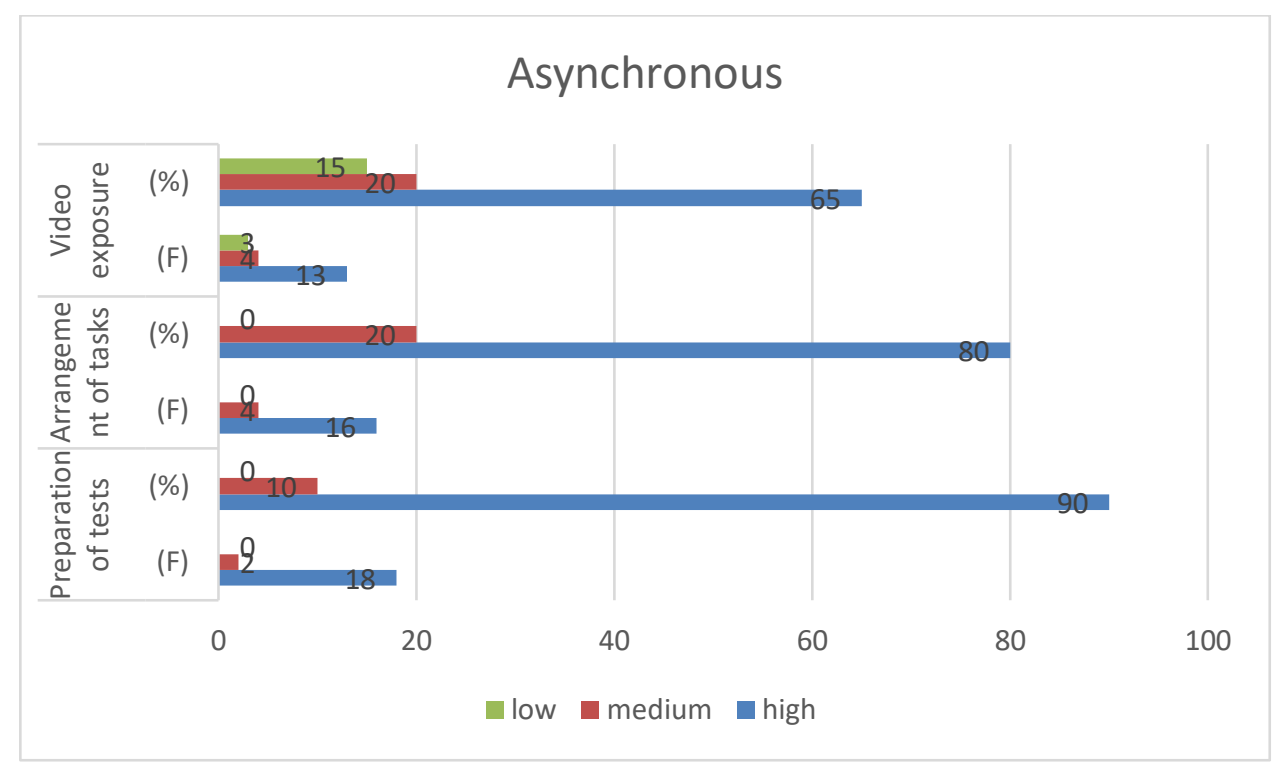

Figure 4. Teacher Performance With Flipped Learning (Asynchronous)

Figure 4 shows that the teacher's performance is a high category with asynchronous activities. The results of the analysis showed that the exposure to the video in the high grade was $65 \%$, the arrangement of the task in the high grade was $80 \%$, and the preparation of the high category test was $90 \%$. However, there is still a percentage of performance in the medium and low categories, although not significant. The cause of the low grade in video presentation is because teachers are not used to teaching in virtual classes, so there are still teachers who take too long in greetings and greetings for up to 3 minutes and are still monotonous in delivery, there is no intonation and variations in video display that are interesting and fun.

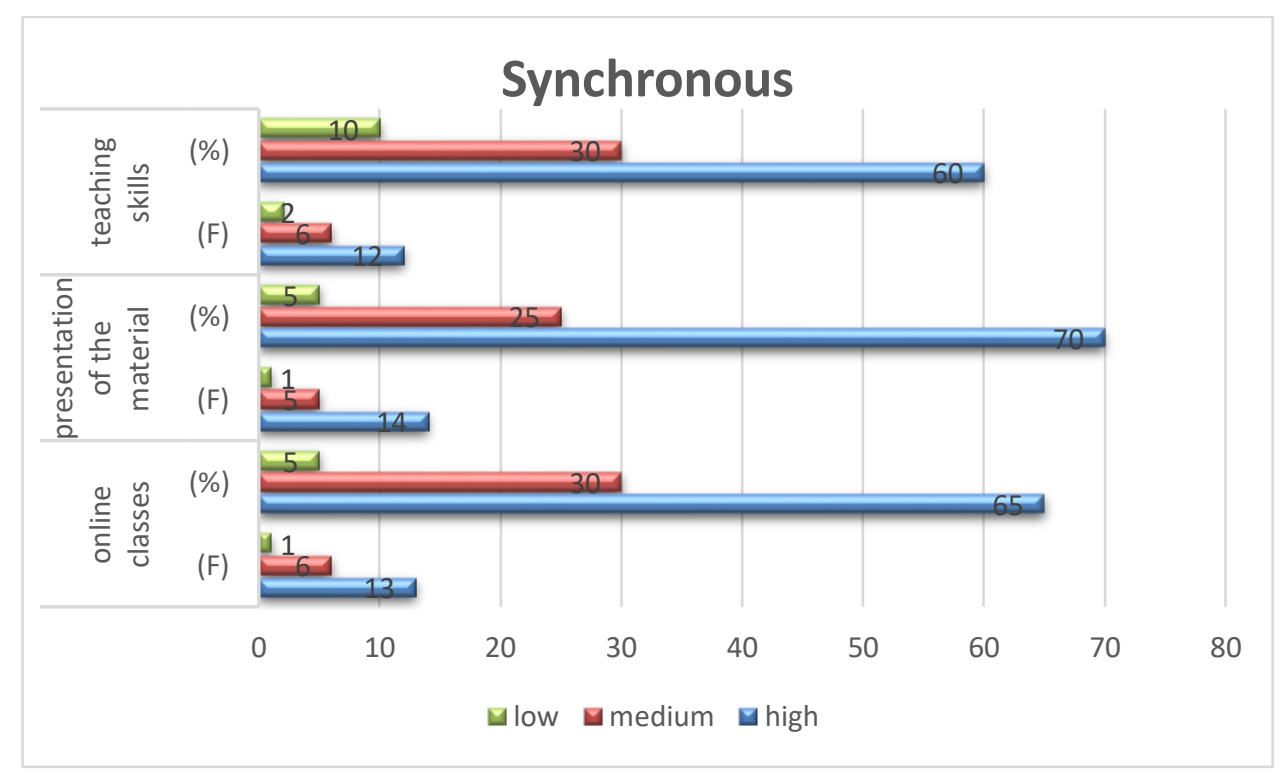

Figure 5. Teacher Performance With Flipped Learning (Synchronous) 
In Figure 5. Shows that teacher performance at synchronous can be categorized as quite good. The results of the analysis show that online teaching skills are $60 \%$ in the high category, the presentation/discussion of online material is $70 \%$ in the high grade, and online learning strategies are $65 \%$. The reason why online teaching skills are still not maximal is that teachers are not used to communicating with students in front of the screen and are still stuttering "mute", sharing materials and initial instructions that should be built so that students are not busy alone or indifferent when online.

\section{Discussion}

Teachers begin to be able to adapt when classroom learning is transformed into online learning by using zoom or filling Google and including synchronous. Understanding When learning outside the classroom is more than at home, it does not mean homework from the textbook. Still, the teacher has adjusted that the teacher can send learning videos and assignments that are relevant to the video given. Researchers found that recorded teacher performance verification was significantly reversed against the reverse learning model when it was asynchronous and synchronous. During the current health crisis, many teachers have had to improvise fast online learning solutions (Hew et al., 2020). The trend in reverse learning studies shows that this method is very effective. Reverse learning has played an important role in traditional educational methods being replaced by non-traditional technology-based methods. The challenge in Flipped Classroom is the use and management of technology (Rindaningsih et al., 2019).Students find active learning pedagogy to be an effective method in the classroom. This method also has a positive effect on student achievement, attitudes, cognitive skills, and soft skills because they are more responsible for their own learning (Birgili et al., 2021).

This model is expertly applied by the teacher because when students are at home, they are maximally studying the material and assignments given through videos. Furthermore, when meeting teachers online with limited time, students can be more active and interactive in presenting and answering teacher questions, even understanding teacher explanations. Similar to the findings on the flipped classroom continuum, which is to prepare the teacher to assess all possible uses of video in the flippedclassroom in order to identify experiences and exploration of subsequent learning (Tomas et al., 2019).

That the hardest part of flipped learning is changing the traditional learning process to the use of videos, online discussion participation, online tests to increase motivation, and students' curiosity races. This process takes quite a long time with quality teachers (Limniou, 
Schermbrucker, \& Lyons, 2018). Flipped learning should start with the teacher summarizing the topic for learning and briefly presenting the activity design, providing examples, and describing the activity model carried out by students (Schoolnet, 2013). Flipped learning is an alternative learning solution during a pandemic. Stacking teachers in active independent education to increase students' sense of responsibility with the support of their learning environment and technology (Chrissi, 2020).

\section{CONCLUSION}

During a pandemic with no known end, it is necessary for the world of education to change the appearance of learning from physical to virtual classrooms. The findings in this study are the percentage of teacher performance is higher in asynchronous than synchronous. This is because the technology factor teachers are not used to all the time, both in digital learning and distance learning classes. The learning model is reversed; the teacher plays a significant role in the teaching process that uses modern technology. The problem of teachers who are still not technology-savvy affects the learning design, both synchronously and asynchronously. The issue of instruments with medium and low categories is based on the adaptation to technology that has not been optimal because they are used to physical classes and schools that lack technology. Thus, the primary solution is support from the government for the internet network and the transfer of physical development to the fulfillment of technology. The challenge for teachers in the reverse learning model in a pandemic is to create a learning environment with learning resources through virtual platforms. Further research, namely, designing a platform that makes it easier for teachers and students to determine learning resources with distance learning conditions.

\section{REFERENCES}

Bakker, A., \& Wagner, D. (2020). Pandemic: lessons for today and tomorrow? Educational Studies in Mathematics, 104(1), 1-4. https://doi.org/10.1007/s10649-020-09946-3

Bergland, J. (2020). Blended, Flipped, and Remote Learning_What's the Difference. TechNotes Blog.

Bergmann, J., \& Sams, A. (2012). Flip Your Classroom. iste.

Bishop, J. L., \& Verleger, M. (2013). The Flipped Classroom : A Survey of the Research The Flipped Classrom: A Survey of the Research.

Birgili, B., Nevra, F., \& Ebru, S. (2021). between 2012 and 2018: A descriptive content analysis. Journal of Computers in Education, 4. https://doi.org/10.1007/s40692-021-00183-y

Chrissi, N. (2020). The use of peer instruction and flipped learning to support flexible blended learning during and after the COVID-19 Pandemic . 7, 184-195.

Daniel, S. J. (2020). Education and the COVID-19 pandemic. Prospects, (0123456789). 
Journal of Elementary Education

Volume 5, Number 1, September 2021
P-ISSN: 2580-9326

E-ISSN: 2580-7714

https://doi.org/10.1007/s11125-020-09464-3

DeSantis, J., Curen, R. Van, Putsch, J., \& Metzger, J. (2015). Do students learn more from a flip? An exploration of the efficacy of flipped and traditional lessons. Journal of Interactive Learning Research, 39-63.

Dick, W dan Carey, L. (2009). The systematic design of instruction. Fifth edition. New Jersey: Pearson Education Inc.

Fahyuni, E. F., \& et al. (2020). Integrating islamic values and science for millennial students' learning on using seamless mobile media. Jurnal Pendidikan IPA Indonesia, 9(2), 231-240. https://doi.org/10.15294/jpii.v9i2.23209

Findlay-Thompson, S., \& Mombourquette, P. (2014). Evaluation of a Flipped Classroom in an Undergraduate Business Course. Business Edication and accreditation, 6(1), 95-108. https://doi.org/10.1080/08832323.1963.10116709

Gonzales, K. P. J. (2020). Rising From Covid-19: Private Schools' Readiness And Response Amidst A Global Pandemic. Ioer International Multidisciplinary Research Journal, 2, 81-90.

Hew, K. F., Jia, C., Gonda, D. E., \& Bai, S. (2020). Transitioning to the "new normal" of learning in unpredictable times: pedagogical practices and learning performance in fully online flipped classrooms. International Journal of Educational Technology in Higher Education, 17(1). https://doi.org/10.1186/s41239-020-00234-X.

Kinshuk, Chen, N. S., Cheng, I. L., \& Chew, S. W. (2016). Evolution Is not enough: Revolutionizing Current Learning Environments to Smart Learning Environments. International Journal of Artificial Intelligence in Education, 26(2), 561-581. https://doi.org/10.1007/s40593-016-0108-x

Kvashnina, O. S., \& Martynko, E. A. (2016). Analyzing the potential of flipped classroom in ESL teaching. International Journal of Emerging Technologies in Learning, 11(3), 71-73. https://doi.org/10.3991/ijet.v11i03.5309

Limniou, M., Schermbrucker, I., \& Lyons, M. (2018). Traditional and flipped classroom approaches delivered by two different teachers: the student perspective. Education and Information Technologies, 23(2), 797-817. https://doi.org/10.1007/s10639-017-9636-8

Lo, C. K., \& Hew, K. F. (2017). A critical review of flipped classroom challenges in K-12 education: possible solutions and recommendations for future research. Research and Practice in Technology Enhanced Learning, 12(1), 4. https://doi.org/10.1186/s41039-016-0044-2

Murphy, E., Rodríguez-Manzanares, M. A., \& Barbour, M. (2011). Asynchronous and synchronous online teaching: Perspectives of Canadian high school distance education teachers. British Journal of Educational Technology, 42(4), 583-591. https://doi.org/10.1111/j.1467-8535.2010.01112.x

Nouri, J. (2016). The flipped classroom: for active, effective and increased learning - especially for low achievers. International Journal of Educational Technology in Higher Education, 13(1). https://doi.org/10.1186/s41239-016-0032-z

Perveen, A. (2016). Synchronous and Asynchronous E-Language Learning: A Case Study of Virtual University of Pakistan. Open Praxis, 8(1), 21-39. https://doi.org/10.5944/openpraxis.8.1.212

Rindaningsih, I., Hastuti, W. D., \& Findawati, Y. (2019). Desain Lingkungan Belajar yang Menyenangkan Berbasis Flipped Classroom di Sekolah Dasar. Proceedings of the ICECRS, 2(1), 41. https://doi.org/10.21070/picecrs.v2i1.2452

Schoolnet, E. (2013). What is the Flipped Classroom model, and how to use it? 
Shahabadi, M. M., \& Uplane, M. (2015). Synchronous and Asynchronous e-learning Styles and Academic Performance of e-learners. Procedia - Social and Behavioral Sciences, 176, 129-138. https://doi.org/10.1016/j.sbspro.2015.01.453

Teng, D. C. E., Chen, N. S., Kinshuk, \& Leo, T. (2012). Exploring students' learning experience in an international online research seminar in the Synchronous Cyber Classroom. Computers and Education, 58(3), 918-930. https://doi.org/10.1016/j.compedu.2011.10.018

Tomas, L., Evans, N. (Snowy), Doyle, T., \& Skamp, K. (2019). Are first year students ready for a flipped classroom? A case for a flipped learning continuum. International Journal of Educational Technology in Higher Education, 16(1). https://doi.org/10.1186/s41239-019-0135-4

Uscher-Pines, L., Schwartz, H. L., Ahmed, F., Zheteyeva, Y., Meza, E., Baker, G., \& Uzicanin, A. (2020). School practices to promote social distancing in K-12 schools: Review of influenza pandemic policies and practices. BMC Public Health, 18(1), 1-13. https://doi.org/10.1186/s12889-018-5302-3 